\title{
The Textual History of the Ethiopic Old Testament Project (THEOT): Goals and Initial Findings ${ }^{1}$
}

\author{
Daniel Assefa \\ Tibeb Research and Retreat Center, Addis Ababa, Ethiopia \\ danielassefakas@gmail.com
}

Steve Delamarter

George Fox University, Portland, OR, USA

sdelamar@georgefox.edu

Garry Jost

Portland, OR, USA

garry.jost@gmail.com

\author{
Ralph Lee \\ soAs University of London, London, U K \\ ralphleerg65@gmail.com \\ Curt Niccum \\ Abilene Christian University, Abilene, TX, USA \\ curt.niccum@acu.edu
}

\begin{abstract}
This article offers an introduction to the Textual History of the Ethiopic Old Testament (ТНЕОт) project. This includes a description of the background to TНЕОт and its primary purpose of mapping the history of the transmission of the Ethiopic Old Testament. The bulk of the article summarizes the project's preliminary findings, generally, and, in particular, about Ethiopic Psalms, Song of Songs, Deuteronomy, Ruth, Amos,
\end{abstract}

1 We thank Alessandro Bausi for reading and responding to earlier drafts of this article. We found his input important for understanding how to shape the final form that appears here. 
Obadiah, Jonah, and Haggai. Some attention is also given to evidences of contact with the Hebrew text tradition, although the Ethiopic is clearly a daughter version of the LXX.

\section{Keywords}

textual criticism - Ethiopic Old Testament - digital humanities - Deuteronomy Ruth - Psalms - Song of Songs - Amos

Good editions of the books of the Ethiopic Old Testament continue to be a desideratum. ${ }^{2}$ The inadequacies of previous publications are well known. In the first place, they were often produced from a single manuscript of the fifteenth or sixteenth century (or later) and compared against only a handful of other similarly dated manuscripts. No matter what formula one uses to calculate a sufficient sample size, such editions fell well below these thresholds. ${ }^{3}$ In the second place, this small sample size rendered it impossible to know even the general contours of the Ethiopic Bible's textual history. Worst of all, the extent of our ignorance of this textual history was so great that it led to a very naïve attitude toward these editions. They were set forth as "the Ethiopic text" and were treated as more-or-less reliable witnesses to what was then called the "Old Ethiopic," which is what we now call the Aksumite Bible. But this earliest form of text, the translations produced in the Christian kingdom of Aksum in the fourth to the sixth centuries CE when Christianity first came to Ethiopia, predates our earliest extant manuscripts by nearly a millennium. It should have been implausible, on the face of it, that manuscripts separated from their initial text (Ausgangstext) by such a long period should be taken

2 To cite just one example, J.M. Harden writes, "In the New Testament also, as in the Old, there is a crying need for the formation of a critical Ethiopic text," in An Introduction to Ethiopic Christian Literature (London: SPCK, 1926), 42. One can find similar comments about the need for Ethiopic Bible editions by leading scholars in virtually every decade of the last century.

3 An important exception is Oscar Löfgren's, Die äthiopische Übersetzung des Propheten Daniel (Paris: Paul Geuthner, 1927), which was based on eighteen manuscripts. Also of note is his Jona, Nahum, Habakuk, Zephanja, Haggai, Sacharja und Maleachi äthiopisch: unter Zugrundelegung des Oxforder Ms. Huntington 625 nach mehreren Handschriften (Paris: Champion, 1930). See also Johannes Bachmann's Dodekapropheton Aethiopum oder die zwölf kleinen Propheten der aethiopischen Bibelübersetzung nach handschriftlichen Quellen herausgegeben und mit textkritischen Anmerkungen versehen (Halle: Max Niemeyer, 1892). 
as reliable presentations of that text. Preliminary data demonstrate that from the fifteenth to the twentieth century there are at least three major stages of development in the Ethiopic Old Testament tradition. It seems prudent to suppose that the previous millennium would have seen at least a similar number of major developments in its history. We have the advantage of hindsight, though, and do not judge previous generations of scholarship for what they could not have known.

It was the microfilm projects of the 1970s, 1980s, and 199os, that began to change the possibilities for textual studies of the Ethiopic Bible, and since the turn of the twenty-first century, the dramatic increase in manuscript digitization has brought us squarely into a new position. By 2011, we could with relative ease access and study more than thirty manuscripts of every book of the Ethiopic Old Testament. It was at this time that the тнеот project began the work of transcribing manuscripts of Ethiopic Obadiah, our pilot project. Six years later, we have substantial sets of manuscript transcriptions (meaning $3 \mathrm{O}^{+}$) for twenty-four books of the Ethiopic Old Testament and are well on the way to gaining at least some general ideas about the nature of the tradition.

The goal of the тнЕот project is to transcribe and statistically analyze variations within thirty or more manuscripts of each book of the Ethiopic Old Testament in order to describe the textual history of each book and to characterize each of its major phases. It is important to note that our goal is not to reconstruct the earliest attainable text, but to understand Ethiopia's history of biblical transmission from the earliest attested text up to today. It is also not part of our goal to produce critical editions of each book, but to lay the foundation for others to do such work. ${ }^{4}$

1.1

The Primary Text Historical Purpose of the Project

Textual traditions offer at least two objects of study: the origins of the tradition(s) and the emerged form(s) of the tradition(s). The search for a tradition's origins is an indispensable task whether pursuing the form of the initial text, first translation, or the Vorlage behind that first translation. ${ }^{5}$ Likewise, the study

4 Small books were fully collated, but for the larger books we selected sample passages based on known Ethiopic variation as well as key variants in Hebrew, Syriac, Coptic, and Greek.

5 Although critical editions of Ethiopic texts present the text in its Ge'ez form, Septuagin- 
of the history of the text illuminates the ever-emerging forms that the text underwent. In particular, those forms that came to dominate certain epochs and regions demand special notice. In theory, we might think it impossible to identify any points in the copying history of a text that are qualitatively different from any other moment of copying. But there are clearly moments in each textual history where forms of the text emerged that gained an ascendancy over the tradition for a limited period. In small and larger ways, the text would continue to change, until another flux moment occurred, when the dominating form of the tradition was replaced by a new majority form of the text. It is precisely on this aspect of the tradition that our project focuses. First, it seeks to identify the forms of the text that dominated certain epochs. Second, it wants to reconstruct and understand the nature of these processes of emergence. What do they tell us about the perceived inadequacy of a previous text form? What types of changes emerged in the processes of transmission history and why?

The study of variants is carried out slightly differently when reconstructing the initial text and when studying subsequent text forms. When reconstructing the initial text, the text critic must produce a stemma, which in part requires making a judgment about the text-critical value of each variant. To put forward a stemma is to identify the extant variants and propose a theory explaining how the variants relate to one another, specifically to describe how one gave rise to the others. Variants that could arise independently through the same common scribal error (polygenesis) do not contribute much to this process, for they cannot be used to prove a genetic relationship among manuscripts.

For the text-historical enterprise, the value of variant readings is measured differently. Although it is helpful to identify the possible forces that gave rise to a text form, in the end the emerged forms of the text are just as important as the generative forces that shaped them. In fact, what is important is not how they originated, but how they gained ascendancy for a certain period. Toward that end, all shared variants are significant text-historically, even if not textcritically. If certain readings characterize a certain text form, regardless of how they arose, they will never be discarded as insignificant for textual history; they are precisely of interest for textual history.

talists - the primary group of Western scholars that have invested much time in the study of the Ethiopic Old Testament-have been interested in the Greek form behind that version. See, for instance, Bachmann's Greek retroversion of the Ethiopic found in Die Klagelieder Jeremiae in der aethiopischen Bibelübersetzung: Auf Grund handschriftlicher Quellen mit textkritischen Anmerkungen (Halle: Max Niemeyer, 1893). 
We mention this last point with a view to the final portion of this article in which we set forth characteristic readings of certain clusters of manuscripts in the textual history of a particular book of the Ethiopic Old Testament. Even though we occasionally comment on scribal error as the primary cause for variant readings, these comments are not intended to be bases for setting these readings aside as text-historically insignificant.

\subsection{The Digital Aspects of the Project}

The тнЕот project uses manuscript image sets from previous microfilming projects such as those of the Ethiopian Manuscript Microfilm Library, ${ }^{6}$ Unesco, ${ }^{7}$ the Library of Congress, ${ }^{8}$ Hammerschmidt, ${ }^{9}$ Davies, ${ }^{10}$ and images of manuscripts microfilmed or digitized by libraries and museums through the first decade of this century. More recently, the digital collections include

6 EMML refers to the Ethiopian Manuscript Microfilm Library, the largest of all microfilm projects conducted in Ethiopia between 1973 and 1993. Some 9,60o manuscripts were microfilmed and a series of catalogues produced: Getatchew Haile and William F. Macomber, A Catalogue of Ethiopian Manuscripts Microfilmed for the Ethiopian Manuscript Microfilm Library, Addis Ababa and for the Hill Monastic Manuscript Library, 10 vols. (Collegeville, MN: Hill Monastic Manuscript Library, 1975-1993).

$7 \quad$ UNESCO refers to the collection of around 370 manuscripts that were microfilmed in Ethiopia between September 1969 and February 1970 by a UNESCO mobile microfilm unit. The Ministry of Education and Fine Arts, Department of Fine Arts and Culture produced a sketchy handlist: Catalogue of Manuscripts Microfilmed by the UNEsco Mobile Microfilm Unit in Addis Ababa and Gojjam Province (Addis Ababa: UnEsco, 20 February 1970).

8 Manuscripts from both the Jerusalem Armenian Patriarchate and the Saint Catherine's collections can be found at the Library of Congress website. See Kenneth W. Clark, Checklist of Manuscripts in St. Catherine's Monastery, Mount Sinai Microfilmed for the Library of Congress, 1950 (Washington, DC: Library of Congress, 1953); and idem, Checklist of Manuscripts in the Libraries of the Greek and Armenian Patriarchates in Jerusalem Microfilmed for the Library of Congress, 1949-1950 (Washington, DC: Library of Congress, 1952). Ernst Hammerschmidt mounted a project in the late 196os to microfilm 182 manuscripts at churches and monasteries around Lake Tana in Ethiopia. Hammerschmidt and Veronika Six published a series of three catalogues: Äthiopische Handschriften vom Ṭānāsee, vонD 20.1-3 (Wiesbaden: Steiner, 1973, 1977, 1999).

10 The manuscripts microfilmed by Donald Davies in Ethiopia were catalogued by William F. Macomber, Catalogue of Ethiopian Manuscripts from Abba Garima, Asatan (Church of Saint Mary), Axum (Church of Zion), Dabra Bizan, Dabra Damo, Dabra Libanos, Gunda Gunde, Kebran, Lalibala (Church of the Savior of the World; Emmanuel Church), Maqale, Ura, Kidana Mehrat, Monastery of Dabra Daga (Church of Saint Stephen), Monastery of Lake Zeway, Dabra Maryam, National Library and Haiq, from Microfilms in the Collection of Dr. Donald Davies, De Land, Florida and Godfrey, Ontario and of the Hill Monastic Manuscript Library, St. John's University, Collegeville, Minnesota (Collegeville, MN: Hill Monastic Manuscript Library, 1979). 
those sponsored by HMML, ${ }^{11}$ EMIP, ${ }^{12}$ EMDL, ${ }^{13}$ EthioSPaRe, ${ }^{14}$ the Endangered Archives Programme (particularly EAP 286 at the Institute of Ethiopian Studies), ${ }^{15}$ collections of Michael Gervers at the University of Toronto, ${ }^{16}$ and an increasing number of image sets from European libraries and museums, among which we give special mention to the Vatican Library and the Bibliothèque Nationale.

We began to enter the domain of what we might call "higher order" digital humanities when we wrestled with questions of how to translate the methods of text-critical analysis into automated processes that the computer could perform. ${ }^{17}$ As we began to think through how to implement text-critical methodology, we crossed a threshold when we saw that the foundation of the entire enterprise needed to be built on the alignment into columns of every word from every manuscript. Therefore at the most basic level we identified text variation units not as passages, nor as phrases within sentences, but words. All words that share the same root were placed in the same column of the spreadsheet, and all

11 Besides being one of the three official partners of the EMmL project, the Hill Museum and Manuscript Library has sponsored several other digitization projects of Ge'ez materials. Among the most significant of these would be a joint project with Michael Gervers, University of Toronto, to digitize the collection at the monastery of Gunda Gunde. A catalogue by Ted Erho is in preparation.

12 EMIP stands for the Ethiopian Manuscript Imaging Project, directed by Steve Delamarter, assisted by Jeremy Brown. Catalogues of the project are published as part of the Ethiopic Manuscripts, Texts, and Studies Series from Pickwick Publications, Eugene, or.

13 EMDL stands for Ethiopian Manuscript Digital Library, the project directed by Meley Mulugetta at the Harriett Tubman Institute in Toronto, Canada. For a number of years, she has been working with the church in Ethiopia, particularly in the northern region of Tigray, to locate, preserve, and digitize manuscripts.

14 Directed by Denis Nosnitsin, the Ethio-SPaRe project (Cultural Heritage of Christian Ethiopia. Salvation, Preservation, Research, of the University of Hamburg) conducted nine missions to Ethiopia between 2010 and 2015, digitizing manuscripts mostly in Tigray. Their website (https://www.aai.uni-hamburg.de/en/ethiostudies/research/ethiospare .html) contains complete reports on all aspects of the project.

15 The project directors were Demeke Berhane, director of the Manuscripts and Archives department at the IES, and Steve Delamarter; Jeremy Brown was director of manuscript digitization. Out of a total of 5,749 items digitized between January and May of 2010, about 1,80o were Ge'ez manuscripts.

16 http://gundagunde.digitalscholarship.utsc.utoronto.ca/islandora/object/ gundagunde\%3Apublic and http://ethiopia.deeds.utoronto.ca, accessed January 6, 2019.

17 This is where the role of our programmer, Garry Jost, became crucial. We exploited the functionality of Google Apps Script, "a rapid application development platform" built into G Suite. See https://developers.google.com/apps-script/overview, accessed January 6, 2019. 
words from all manuscripts receive a column. The most significant implication of this approach is that every detail of every manuscript is in the dataset and virtually all of it can be analyzed, aggregated, separated, or otherwise manipulated for analysis. ${ }^{18}$

\section{Initial Findings}

While there are a few disadvantages to the тнЕот methods, the main advantage is that its statistical approach offers the ability to describe with precision both large patterns in the tradition as well as many minute phenomena. ${ }^{19}$ The initial results shared below will illustrate the benefits of this approach.

18 In dialogue with the rest of the team, Jost created programs in Google scripts that validate the formatting of the document holding the aligned texts, determine for each column the number of variants and assign a numerical value to each, profile the variants of each manuscript in each column against those assigned values, tally the percentage agreement of each manuscript with every other manuscript, create a statistical profile of every manuscript in terms of unique plusses and minuses, create "comma separated value" (csv) files for R statistical package from which dendrograms are generated, identify and list the distinctive readings of clusters of manuscripts (with the Ge'ez text included for analysis), identify and profile the best representative manuscript of each cluster, profile the secondary and tertiary affiliations among the manuscripts (i.e., those readings that each manuscript shares with manuscripts outside its primary cluster), and analyze the diachronic developments of variants from cluster to cluster. Each of these scripts render data which, when interpreted, illuminate the various aspects of historical developments among the manuscripts.

19 Perhaps the greatest disadvantage involves the necessity of ignoring the nuancing of words (through prefixes, suffixes, and infixes) when aligning columns solely on the basis of shared roots. This decision obliterates all of the categories of evidence that Semitic languages encode in their morphological systems for nuancing a morpheme: singular and plural nouns, number in verbs, aspect of verbs, indicative and interrogative, etc. These categories are not insignificant, but the information gleaned from scripts that were programmed to distinguish among all of these options would deliver very little more about textual history than what is gleaned without these distinctions. The scripts could actually accommodate such information, but we judged that the programming challenges and additional time in formatting were prohibitive and, in the end, unnecessary for the project goals. Another significant disadvantage is the potential obfuscation of larger variation units and their impact on calculations of agreement with other witnesses. Even with the rich dataset provided by computer analysis, primary investigators must still examine all variations in context to provide a more accurate assessment. 


\subsection{Uniformity of Tradition}

Perhaps the single most important aspect about the Ethiopic Old Testament tradition is its remarkable uniformity. ${ }^{20}$ With a few exceptions at the periphery, the extant manuscripts of the last seven centuries reveal a tradition in which the vast majority of textual variation is played out in just 9 to 12 percent of the words in any given book. (Fig. 1 illustrates the high level of consanguinity found across fifteen books.) This makes it clear that the Ethiopic tradition descends from a single recension. Even if one can demonstrate that a cluster of manuscripts within the Ethiopic tradition shows evidence of influence from Arabic versions, for instance, it is questionable to refer to this cluster as a "recension" when the net impact of all variants is so minimal.

The level of textual variation among the extant Psalter manuscripts is very nearly a full order of magnitude smaller than with the rest of the books of the Ethiopic Old Testament that we have studied thus far. Most of that variation takes place within 1.4 percent of the words; all of it takes place within 2.5 percent. The reasons for this remarkable stability are undoubtedly found in the holding force of the chanting community. They did not just read the text; they memorized and recited the text on an almost daily basis, even when Ge'ez ceased to be a commonly understood language in Ethiopia.

\subsection{Transmission History}

Examining the small percentage of variation that does exist within the overall tradition, we have identified clusters of manuscripts that share similar readings. These clusters appear to delineate the main phases of Ethiopic textual history, because 1) the preponderance of manuscripts in a cluster comes from the same epoch, ${ }^{21}$ and 2 ) even when we use completely different manuscripts from book to book, the same clusters from the same timeframes appear.

The earliest attested manuscripts, from the fourteenth to the sixteenth centuries, contain a set of distinctive readings that set them off from other manuscripts as an identifiable "supercluster," i.e., a conglomeration of related witnesses made up of two or more clusters. (The boxes on the left side of Fig. 2

20 This is, perhaps, even more remarkable given the substantial number of variant recensions within the Arabic Old Testament tradition that permeated the ecclesial environment in Egypt, which was traditionally above Ethiopia in the church hierarchy.

21 Though it is always possible for later manuscripts to carry earlier texts, this is actually a rare phenomenon in the manuscripts studied thus far. It seems clear that it is not the antiquity of a text form that drives decisions about what specific text will be copied into a new manuscript but fidelity to the unfolding received text. 


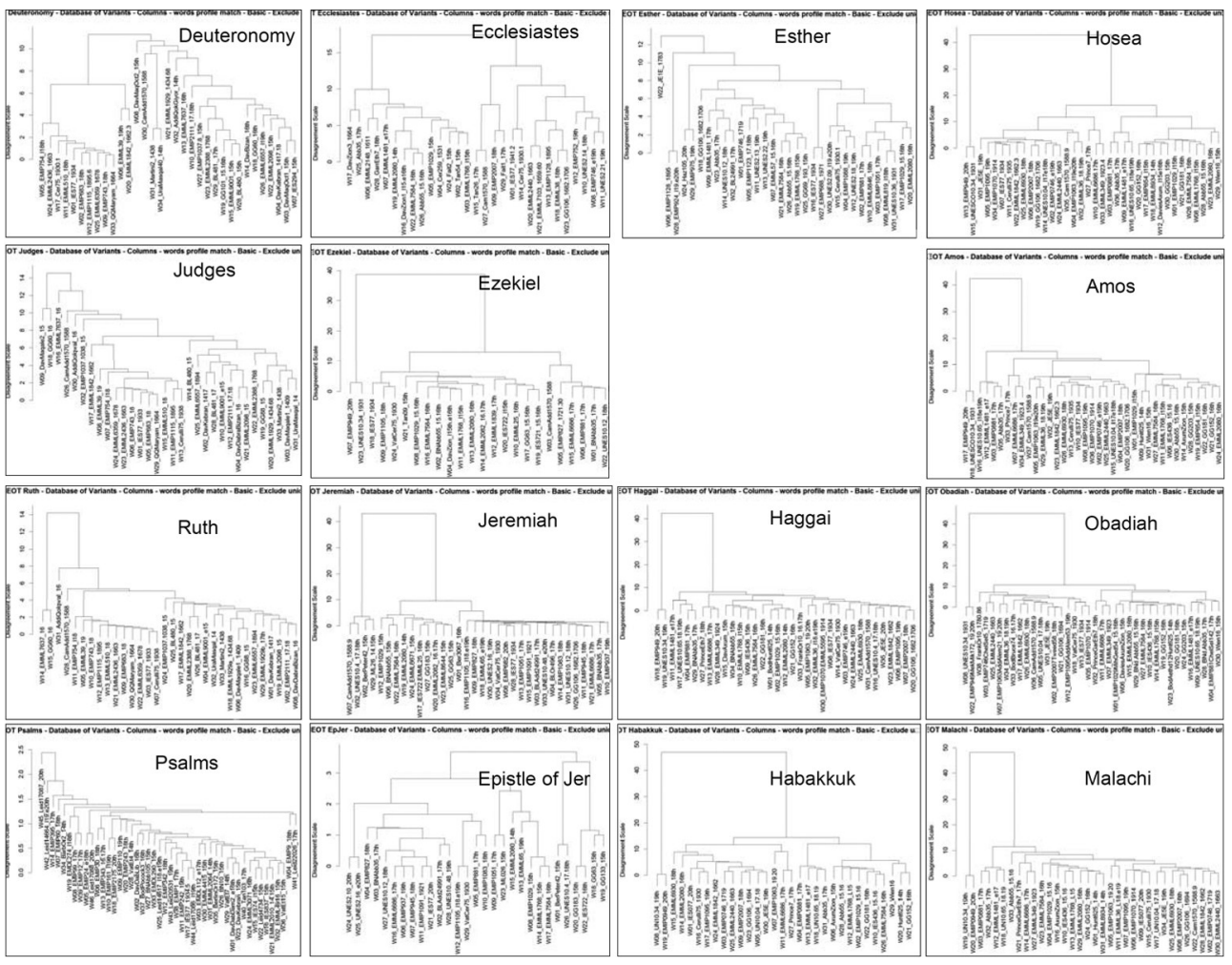

FIGURE 1 Dendrograms of fifteen books of the Ethiopic Old Testament showing the general agreement in wording across the tradition

encompass the early witnesses of Amos. ${ }^{22}$ ) Within that early supercluster, though, there are almost always at least two competing forms of the text. One of these clusters is often discernible as an attempt to improve the other. We refer to this particular form as a "Transitional Text," i.e., one that shares most of the readings of the earliest extant supercluster, while at the same time setting the stage for the next major cluster to emerge in the tradition. ${ }^{23}$

22 The dendrograms presented in Fig. 1 display agreement in wording. By focusing on agreement in variation (Fig. 2), the manuscript and cluster relationships become more sharply defined.

23 In other books, the Transitional Text would appear in a grouping similar to that which is found in the box farthest to the left in Fig. 2. Amos, however, lacks a Transitional Text. Here the box delineates codices that descend from a poorly copied exemplar of the earliest attested text. Most of this group's distinctive readings are scribal blunders. 


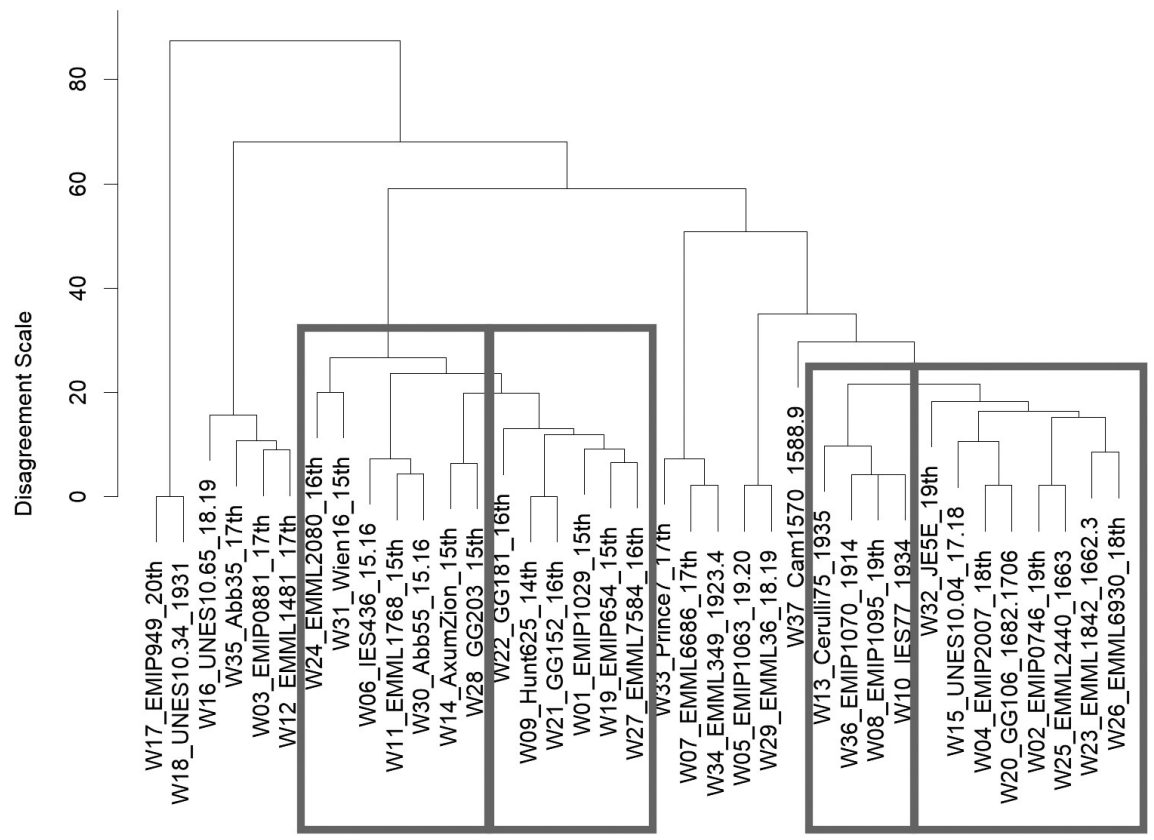

FIGURE 2 Dendrogram displaying agreement in variation in Amos

Most of the newer manuscripts fall into a second supercluster. For Amos, the boxes on the right (Fig. 2) demarcate that group. Within this supercluster of younger witnesses, a major cluster, usually the largest, surfaces in the sixteenth and seventeenth centuries. We refer to this as the Standardized Text because the large number of manuscripts and their greater degree of uniformity appear to indicate a program of standardization sponsored by the combined authority and resources of church and state. ${ }^{24}$ It is often possible to show that this form of the text is based on a manuscript of the Transitional Text. The move from the earliest extant form of the text to the Standardized Text represents the major watershed of the extant Ethiopic Old Testament textual history.

Finally, a third major cluster emerges in the nineteenth and twentieth centuries as the form of the text we call the modern Textus Receptus. This form of the text is usually grounded on the Standardized Text. In fact, the modern Textus Receptus occasionally simply adopts the Standardized form of the text with only minimal changes. But usually this cluster is set off by a discernible

24 The Standardized Text of Amos is framed by the box farthest to the right in Fig. 2. 
set of distinctive readings. ${ }^{25}$ These three stages of the text, then, constitute the heart of the Ethiopic tradition and usually account for more than 85 percent of all the manuscripts.

Small clusters of manuscripts with a high degree of variation from the primary text forms described above are an indication of interesting and rare forms of the text. For instance, we identified two manuscripts that carried texts that were virtually identical to one another, but diverge significantly from all other clusters. ${ }^{26}$ We were able to determine that the text had been translatedcomplete with versification and chapter summaries-from a Latin Vulgate edition. ${ }^{27}$ Martin Heide, who is completing a critical edition of the Ethiopic Jeremiah cycle, has isolated another small cluster of early manuscripts of Jeremiah that vary from the other earliest-attested manuscripts to a very high degree (around 45 percent). ${ }^{28}$ The cluster's differences reflect dependence on an Arabic Vorlage of Jeremiah that can be described as an amplified version of the Hebrew text. We have a similar case with a small cluster of later manuscripts of Ethiopic Daniel translated from an Arabic source containing both text and commentary. Cambridge Additional 1570 is a manuscript with many unique readings, produced in a unique historical setting, perhaps by a Jewish scribe. It shows some of the earliest evidence in the tradition of influence from the MT (more on this below). The point here is that the large data set clarifies not only the main trunk of the tradition, but also identifies movements at the margins of transmission history. We can identify them and analyze them, but we can also maintain perspective about their impact on the tradition.

At this point, we provide a few distinctive readings that demarcate the main stages of the textual history of the Ethiopic Old Testament. This is true of both

25 Note the box to the left of the Standardized Text witnesses in Fig. 2. Manuscripts not enclosed in boxes, apart from $\mathrm{W}_{17}$ and $\mathrm{W}_{18} 8$ that represent a Latinized revision (see below), attest other stages of development shaped to varying degrees by the Arabic and/or Hebrew.

26 EMIP 949 (Makelle Mika'el Church, 172), containing Enoch (1 $\left.{ }^{\mathrm{r}}\right)$, Tobit $\left(66^{\mathrm{r}}\right)$, Minor Prophets $\left(72^{\mathrm{v}}\right.$ ), Ezekiel (fol. 105 ${ }^{\mathrm{r}}$ ); and UnESCO 10.34 (Qeddus Giyorgis Church, Dimma Monastery, Gojjam), containing Daniel $\left(4^{\mathrm{r}}\right)$, Minor Prophets $\left(39^{\mathrm{v}}\right)$, and Ezekiel $\left(105^{\mathrm{r}}\right)$.

27 Note $\mathrm{W}_{17}$ and $\mathrm{W}_{18}$ in Fig. 2. It was Jeremy Brown who discovered and connected the two manuscripts; it was Curt Niccum who traced their origin to the Sixtine Vulgate.

28 Garry Jost and Steve Delamarter led a тнеот team that transcribed and analyzed the data from thirty manuscripts of Jeremiah ch. 2. We presented our findings at The Ethiopic Jeremiah-Cycle: A Critical Edition Project Workshop 4-5 October 2016, Marburg. See "The Digital Methodology of the Textual History of the Ethiopic Old Testament (тнеот) Project Applied to Ethiopic Jeremiah 2," in the forthcoming proceedings volume edited by Stefan Weninger. 
the readings that separate the earlier texts from later ones and those changes distinctive of more narrowly defined clusters such as the Transitional Text, Standardized Text, modern Textus Receptus, and even smaller groupings.

As a point of reference, Greek and Hebrew readings are provided since it is assumed that the earlier text forms preserve significant portions of the original translation from the Greek and the later text forms display changes toward the Hebrew, although almost always the latter are introduced from an Arabic source. ${ }^{29}$ Rarely do we note Greek and Hebrew variants, even when they might correspond better to the Ethiopic reading(s) being discussed. ${ }^{30}$ It is not our goal at the moment to determine origins of readings. Rather we seek instead to trace the history of transmission through those readings. This is not to dismiss questions of origin, for they are important for every new reading and new cluster, as a few of the observations below will substantiate.

\subsubsection{Psalms $s^{31}$}

We mentioned above that the manuscripts of Psalms have a degree of variation that is one-tenth of the usual variation in the other books of the Ethiopic Old Testament. Out of the sample passages, consisting of approximately fif-

29 These historical developments have been observed in virtually every Old Testament book, but they have been most clearly documented in Löfgren's Daniel, i-liv, and in his textual commentary on pages 89-157.

30 For example, many of the newer Ethiopic readings align not just with Hebrew/Arabic but also with the Lucianic Greek text when it differs from $\mathrm{LXX}^{\mathrm{B}}$ text. Historically and linguistically, though, the evidence points to engagement with non-Greek sources making the more recent Ethiopic variants useless for textual criticism of the Greek Old Testament. For overviews of external influences on specific books of the Ethiopic Bible, see the relevant entries in Brill's Textual History of the Bible, e.g., Curt Niccum, "19.4.3 Ezra Nehemiah: Secondary Translations: Ethiopic Translation(s)," in Textual History of the Bible, vol. 1: The Hebrew Bible, part 1c: Writings, ed. A. Lange and E. Tov (Leiden: Brill, 2017), 1187-1192.

31 Steve Delamarter provides this survey of the evidence for Psalms based on the work of Albert ten Kate, Principal Investigator, Marc Malevez, and himself. Seventy-two test passages, representing 7.5 percent of the book, were collated: Pss 2:2; 4:8; 9:33, 37; 12:1-3; 13:1-3; 15:3, 11; 17:14, 23; 20:10, 12; 21:15-16, 20; 26 superscription, 4-6; 31:3, 6; 34:20; 36:19-20, 28; 37:5, 21; 39:10-11, 17; 40:7-9; 45:6; 48:20; 50:3, 9; 54:11; 55:3, 5-6; 59:4; 62:6; 64:1-2, 5; 66:5; $67: 5,9,13,18-19 ; 72: 6 ; 73: 14,17$; 8o superscription, 9; 88:40, 43, 47-49; 92 superscription, 3 ; 94:4; 95:9-10; 96:9; 103:28-29; 111:8-10; 115:4; 118:113, 115, 136, 139; 120:3; 123:2-7; 128:8; 134:1719; 139:12-13; 142:10, 12; 144:6-7; 146:10; 149:6-7; and 151:6. The following manuscripts were employed: Berlin Or. 172; BN 10; BN Abb 105; Bod Pocock 3; Davies Dabra Damo Reel 2; Davies Dabra Libanos; Davies Kebran Reel 2; EMDL 112, 274, 29 O; EMIP 1, 9, 12, 24, 30, 6o, 99, 110, 161, 242, 243, 342, 343, 395, 2175; IES 74, 77, 837; EMML 2O10, 2064, 3071, 4415, 4916; Leiden Or. 4734, 14617, 14664, 17086, 17087, 17088, 20531, 22026; Tanasee 103; Vatican Et. 4, 7, 15; and Vatican Barberini Orientalis 2. 
teen hundred words, we found only six one-word readings that consistently appeared in clusters of older manuscripts and not clusters of younger manuscripts: ${ }^{32}$

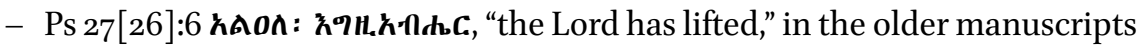

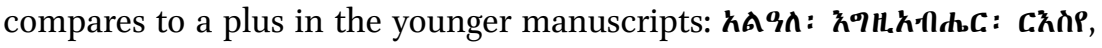

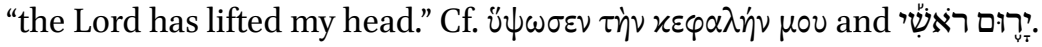

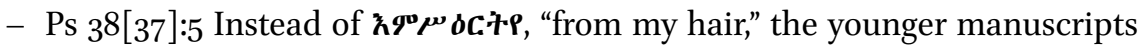

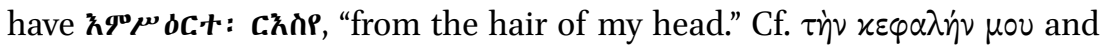
ראטֶָׁי

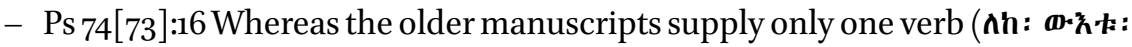

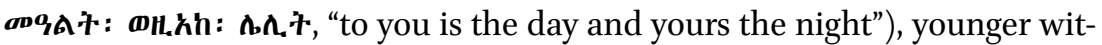

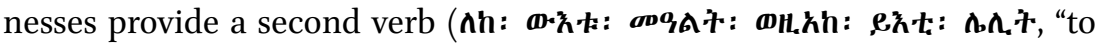

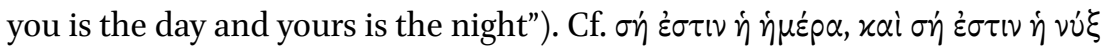

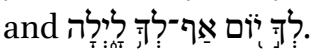

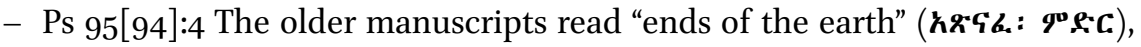

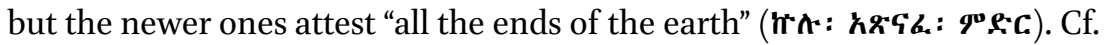

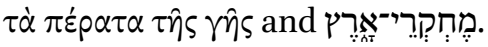

- Ps 96[95]:9 Older codices refer to "his face" (12.) and younger ones to "the

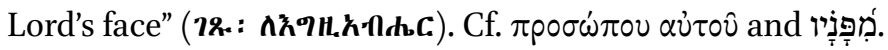

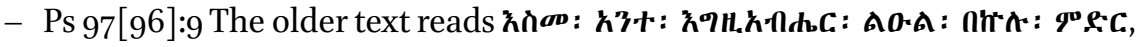
"For you are the Lord, high in all the earth." The younger reading specifies

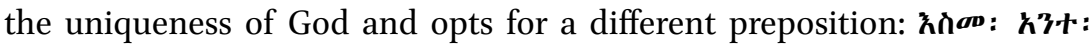

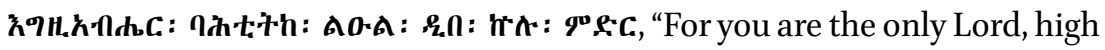

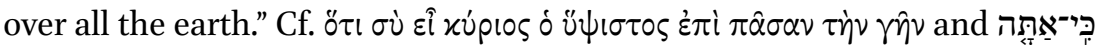

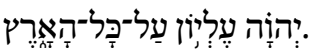

Psalm 151 represents a very interesting exception to the remarkable uniformity of the text of the Ethiopic Psalter. ${ }^{33}$ The oldest superscriptions to the psalm

32 Chapter and verse numbers are first provided according to the Hebrew and most Protestant Bibles with the numbering of the Greek and other Christian traditions provided in brackets. Most Hebrew, Greek, and Latin citations are provided by www.academic-bible .com.

33 See Steve Delamarter and Cameron Marvin, "12.6 Psalm 151: Secondary Translations: Ethiopic Translation(s)," in Textual History of the Bible, vol. 1: The Hebrew Bible, part 1c: Writings, ed. A. Lange and E. Tov (Leiden: Brill, 2017), 302-307; and Steve Delamarter, "The Cave 11 Psalm Scroll (11Q5) and the Textual History of Ethiopic Psalm 151: Memory and Interpretation of David as Anointed Warrior," in The War Scroll, Violence, War and Peace in the Dead Sea Scrolls and Related Literature, Essays in Honour of Martin G. Abegg on the Occasion of His 65th Birthday, ed. Kyung S. Baek et. al, STDJ 115 (Leiden: Brill, 2015), 390-407. This study was based on transcriptions of the entire psalm in forty-five manuscripts: Davies Axum 3; Davies Dabra Damo Reel 2; Davies Dabra Libanos; EMDL 112, 274, 290; EMIP 11, 


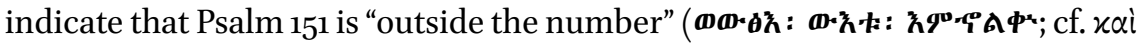
$\tilde{\varepsilon} \xi \omega \theta \varepsilon \nu \tau 0 \hat{v} \alpha p(\theta \mu \circ \hat{v})$, which may have allowed for a different set of dynamics to be at play in its transmission. The psalm actually has three one-word "hotspots"

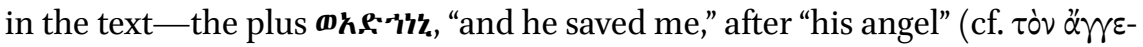

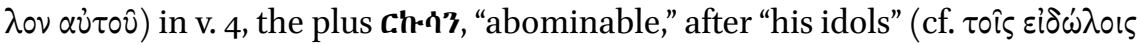

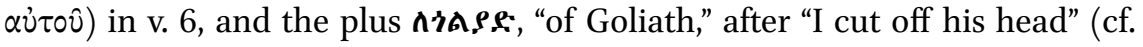
$\dot{\alpha} \pi \varepsilon \kappa \varepsilon \varphi \dot{\alpha} \lambda(\sigma \alpha \alpha \dot{\tau} \tau \dot{\partial} v)$ at the end of v. 7 -and one large hotspot of three strophes

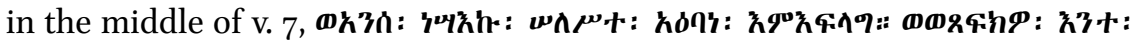

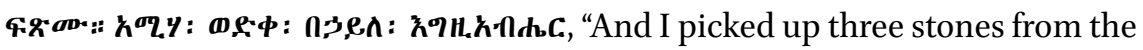
brook, and cast it to his head, when he fell down by the power of God." It is remarkable that these four hotspots each have their own textual history. By the end of the sixteenth century, the first variant had been fully adopted by the tradition. The second through the fourth variants appear in the seventeenth and eighteenth centuries, but their adoption each follows a different timetable with differing degrees of adoption by the manuscripts.

\subsubsection{Song of Songs ${ }^{34}$}

The Song of Songs is the most copied book of the Ethiopic Old Testament because it appears in virtually every Psalter, in biblical manuscripts containing the Solomon corpus, as one of the biblical texts in the Lectionary for Passion Week, and also in the Funeral Ritual. There are three distinct recensions of the Ethiopic Song of Songs. ${ }^{35}$ The common recension is the one that is most frequently copied and represents a fairly straightforward translation of the Greek text. This recension appears in the extant manuscripts of all periods, from the fourteenth century to the present. A second recension contains fully 128 additional strophes spread fairly evenly throughout the book. These strophes reflect extensive poetic, linguistic, aesthetic, and theological interests. The earliest manuscript of this recension is EMML 2064, from the fifteenth century. We know of only twenty codices that contain some or all of the strophes associated with this recension; a later hand often adds the strophes interlinearly. A

14, 22, 24, 30, 35, 44, 48, 6o, 99, 110, 161, 242, 243, 342, 343, 395, 1055, 106o, 2175; IES 74, 77, 837; EMML 2O10, 2064, 2496, 2497, 26o2, 3071, 3112, 4415, 4916, 6531; Tanasee 103, 166; UNESCO 2.84; UNESCO 10.16; and Yale Ethiopic 18.

34 Steve Delamarter provides this survey of the evidence for Song of Songs based on his work as the Principal Investigator. About 85 o Psalters have been probed to this point. The study is based on the full transcription of eighty manuscripts: thirty-one of the common edition, twenty-nine of the Scholars recension, and twenty of the Old Giyorgis recension.

35 Here it would be correct to employ the term "recension," indicating significant editorial differences. 
third recension is clearly related to the second. It contains all of the additional strophes of the previously mentioned recension after Song 2:15, but none of the additional strophes before that point. This recension appears first in manuscripts of the seventeenth century, and there are perhaps seventy copies of them extant. This seems to indicate that while the second recension was relatively unknown, the third recension enjoyed widespread circulation, and presumably the authorization of the hierarchy of the church. We do not yet know why or how the third recension lost the early strophes of the second recension. The manuscripts of this third recension become more and more frequent as we approach the late nineteenth and early twentieth centuries and are especially common as products of the scriptoria of Emperor Menilek, Empress Zewditu, and Emperor Haile Selassie. ${ }^{36}$ We accept as a working hypothesis Roger Cowley's proposal that the added strophes in both these recensions originated with the venerated Ethiopian literary and theological genius, Giyorgis of Sagla or Gassacha. ${ }^{37}$ We refer to the second recension as the "Old Giyorgis" recension and to the third as the Scholars Edition, though the traditional ascription is the Hebraist Edition. ${ }^{38}$

\subsubsection{Deuteronomy ${ }^{39}$}

The collated manuscripts clearly fall into two main clusters of older and younger manuscripts. These are distinguished from one another in various ways, the most significant being:

36 See the notes in the Introductions to the Catalogues of the Ethiopic Manuscript Imaging Project (published in the series Ethiopic Manuscripts, Texts, and Studies [Eugene, or: Pickwick Press]) 2009-present.

37 See "Giyorgis of Sagla," in Encyclopedia Aethiopica 2:812.

38 The label "Hebraist" is misleading, for the edition exhibits no direct Hebrew influence. The designation likely derives from one of the additional strophes at 8:5-6: “'Under an apple tree I awakened you'; which means in Hebrew language, 'They who are anointed by the blood of the goat of Gilead."

39 Ralph Lee provides this survey of the evidence for Deuteronomy based on his work as the Principal Investigator. The following passages represent the sample of the book (about 10 percent) that was transcribed: Deut 1:15, 39-40; 2:3, 11; 3:11, 20; 4:12, 45; 5:15-19; 6:18; 7:15, 17, 22-23; 8:18; 9:18; 11:10, 21, 23; 12:2; 13:2, 4-5; 14:7, 15:2, 15, 18; 16:15-16; 17:5, 19; 18:5; 19:56, 21; 21:4, 7, 15; 22:1; 23:13, 18; 24:2, 5; 25:4; 26:18-19; 27:3-4; 28:19, 53; 29:20; 30:7, 9; 31:1, 9, 15,$21 ; 32: 2,8,22-23 ; 33: 44-45 ; 34: 4,6$. The following manuscripts were transcribed: Addi Qolqwal Giyorgis (Ethio-SPaRe); BL 480; B L 481; Cambridge Add. 1570; Davies Dabra Bizan; Davies Kebran; Davies Lake Zeway; Davies Makelle Octateuch 1; Davies Makelle Octateuch 2; ЕMIP о683, о743, О754, 1037+1038, 1115, 2111; EMML о039, O510, 1842, 1929a, 2098, 2388, 2436, 6359, 6557, 7637, 90o1; Gunda Gunde 6o, 101; IES 077, 294; Martini etiop. 2 (Bibliotheca Forteguerriana di Pistioa); Qaqama Qeddest Maryam Dabra Gannat (Ethio-SPaRe); Ura Masqal 40 (Ethio-SPaRe); Vat Cerulli 75 . 


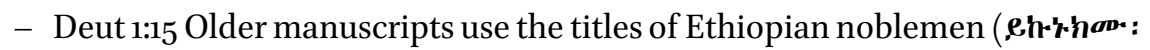

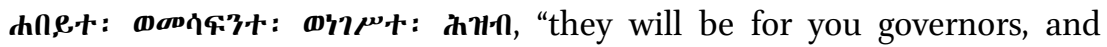
princes, and rulers of the people,") and the newer clusters have a more literal

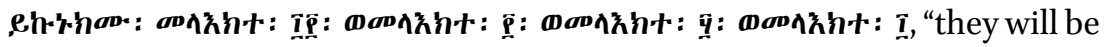
for you leaders of a thousand, and leaders of a hundred, and leaders of fifty,

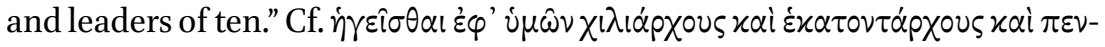

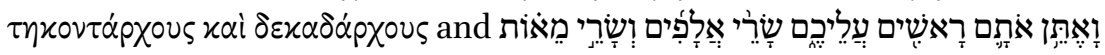

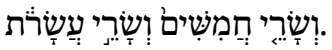

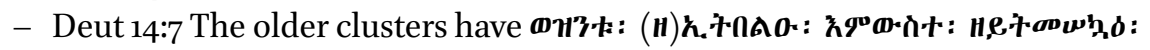

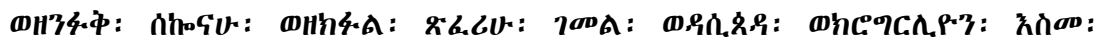

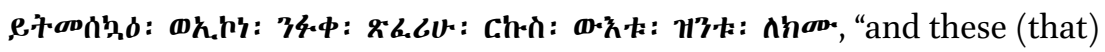
you shall not eat from among those that chew the cud and whose hoof is cloven and whose claws are divided: the camel and hare and rabbit, because they chew the cud but their hoof is not cloven and this is unclean for you." This text follows LXX, and the animal names are transliterations of the Greek:

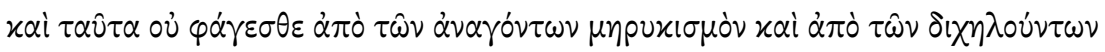

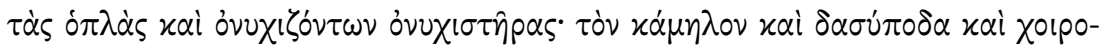

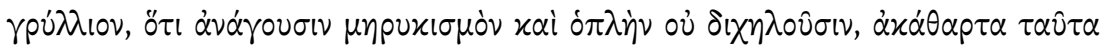

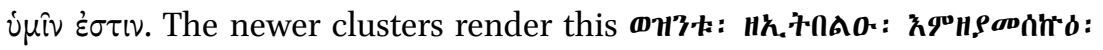

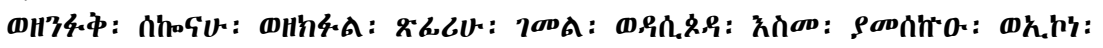

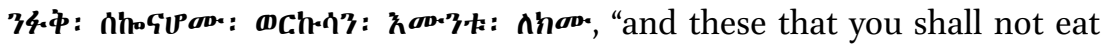
(are) from those that chew the cud and whose hoof is cloven and whose claws are divided: the camel and hare, because they chew the cud but their hoof is not cloven and they are unclean for you, and the rabbit and pig because their hoof is cloven but they do not chew the cud and they are unclean for you." The principle difference here is the relocation of the rabbit into a further list of animals that have a cloven hoof but do not chew the cud.

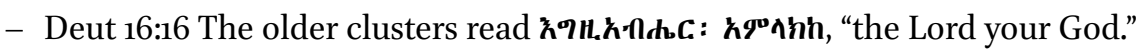

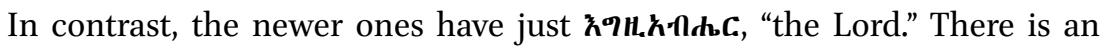
apparent tendency in older clusters to make the address "the Lord your God"

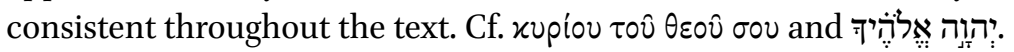

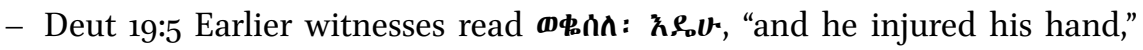

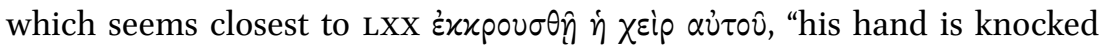

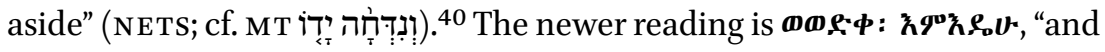
it fell from his hand." 
- Deut 23:17[18] Between the topic of female and male prostitutes, the older

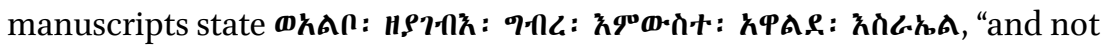
one who will bring into service from among the daughters of Israel," whereas

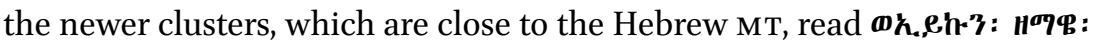

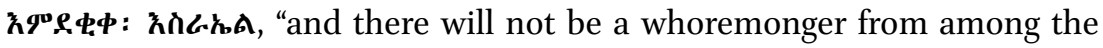

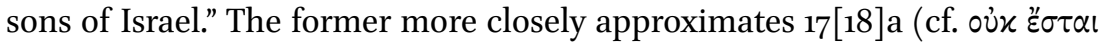

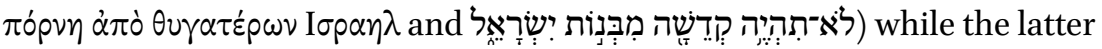

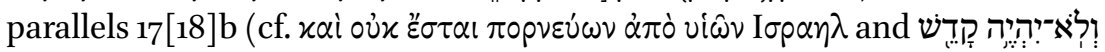

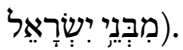

The differentiation between the two main clusters of the older branch is complex, and it has not yet been possible to establish the precedence of one over the other.

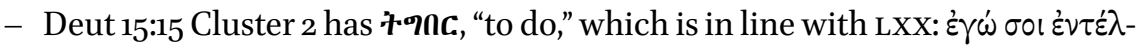

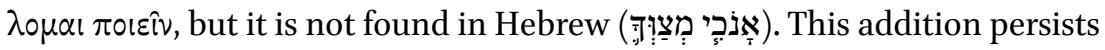
in the later witnesses.

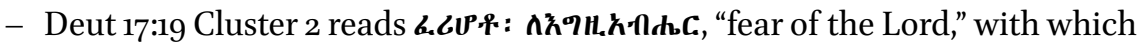

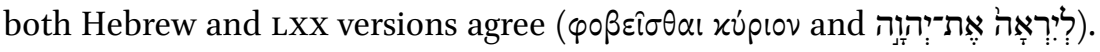

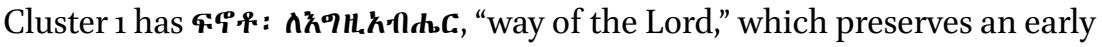
scribal error that has persisted through to the Standardized Text and the modern Textus Receptus.

- Deut 32:2 Differences between the two clusters of earliest attested manuscripts often concern the choice of vocabulary. (See also the comments on

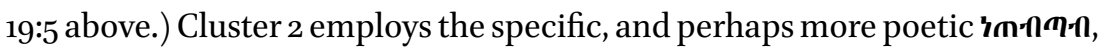
"drops of moisture," whereas Cluster 1 uses the more generic 1Fq "rain." Cf.

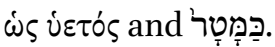

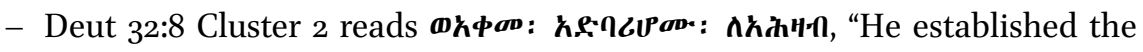

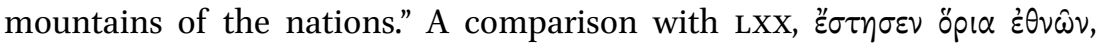

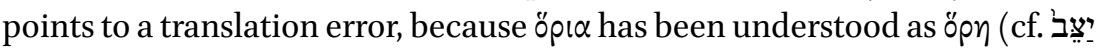

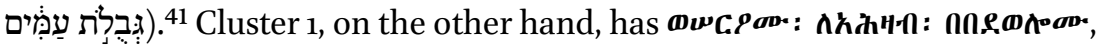
"he established the borders of the nations."

Differentiation between clusters of the newer manuscripts is straightforward. The Transitional Text has many differences from the Standardized Text and the modern Textus Receptus. Hence the Transitional Text of Deut 31:9 includes ถ'าน, "the word(s)" (= $\tau \dot{\alpha} \dot{\rho} \eta \dot{\eta} \mu \alpha \alpha)$ found in the earliest attested clusters, but

41 A thirteenth century or earlier fragment provided by Loren Stuckenbruck reads $\boldsymbol{\omega} \boldsymbol{\lambda} \boldsymbol{\phi} \boldsymbol{\sigma a}$ :

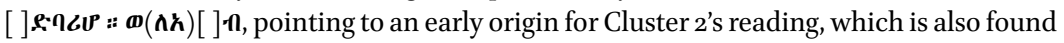
in five manuscripts from Cluster 3 and persists through to the Standardized Text and modern Textus Receptus. 
missing from the Standardized Text and the modern Textus Receptus (as also Hebrew). As noted above, sometimes we see an early reading return in later stages of transmission. For example, at Deut 5:15, the earliest extant witnesses

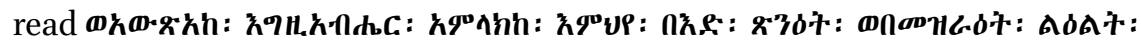

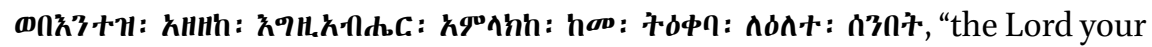
God brought you out from there with a strong hand and with a high arm, therefore the Lord your God commanded you to keep the day of the Sabbath."

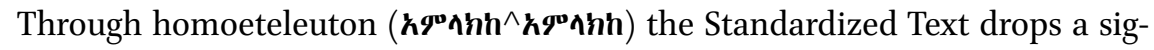

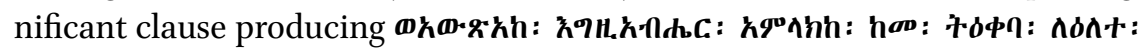
n3n', "the Lord Your God brought you out to keep the day of the Sabbath." The lost clause is recovered in the modern Textus Receptus.

\subsubsection{Ruth ${ }^{42}$}

As with the other biblical books, the older and newer branches of the Ethiopic tradition are clearly delineated by plusses, minuses, and substitutions.

- Ruth 1:8 The earliest attested text reads "return each of you to her mother's house." The younger manuscripts (the Standardized Text and modern Textus Receptus) have a plus: "return each of you to the house of your father and of

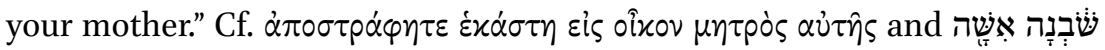

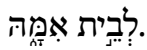

- Ruth 1:9 The earliest attested text reads "rest," while the younger clusters have "mercy and rest," a plus found neither in LXX or Hebrew MT ( $\dot{\alpha} \nu \alpha \dot{\pi} \alpha \nu \sigma \omega \nu$ and

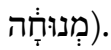

- Ruth 2:7 The later clusters improve the style. The Standardized Text and the

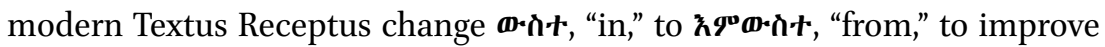
the flow of the sentence. Cf. $\varepsilon v$ and

- Ruth 4:17 The later clusters remove a stylistic difficulty. Here the earliest

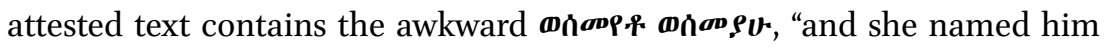
and they named him." The Standardized Text and the modern Textus Recep-

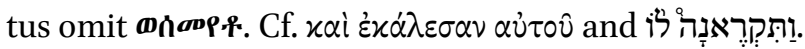

42 Daniel Assefa provides this survey of the evidence for Ruth based on his work as the Principal Investigator. The entire book of Ruth was transcribed from the following manuscripts: Addi Qolqwal Giyorgis (Ethio-SPaRe); BL 480, 481; Cambridge Add. 1570; Davies Dabra Bizan; Davies Kebran; Davies Lake Zeway; Davies Makelle Octateuch 1; EMIP o683, o743, O754, 1037+1038, 1115, 2111; EM ML 0o39, O510, 1842, 1929a, 1929b, 2098, 2388, 2436, 6359, 6557, 7637, 90o1; Gunda Gunde 6o, 88; IES 77; Martini etiop. 2 (Biblioteca Forteguerriana di Pistoia); Qaqama Qeddest Maryam Dabra Gannat (Ethio-SPaRe); Ura Masqal (Ethio-SPaRe); and Vat Cerulli 75 . 
- Ruth 1:2 In this passage, we find an example of a later substitution. The ear-

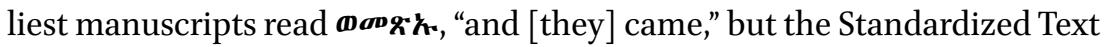
and the modern Textus Receptus supply $\boldsymbol{\Phi}_{\boldsymbol{\alpha}}<$, "and they went." Cf. $x \alpha i$ i " $\lambda \theta_{0-}$ $\sigma \alpha \nu$ and

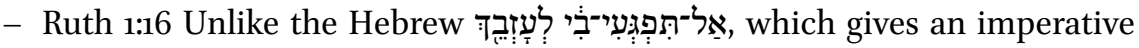
(a demand to Naomi), the Greek and the Ethiopic express the reaction or

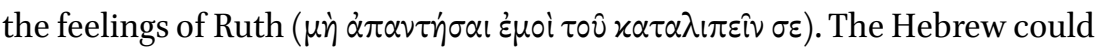
mean "Do not push me to leave you," but the Greek seems to say, "Let this not happen to me, to leave you ...." The earliest Ethiopian manuscripts render

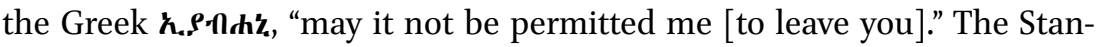

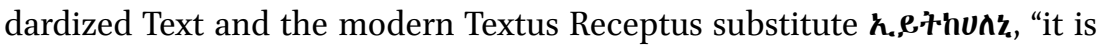
not possible for me," which improves the reading. Such a change does not require influence from another version.

- Ruth 2:16 The Standardized Text and the modern Textus Receptus have

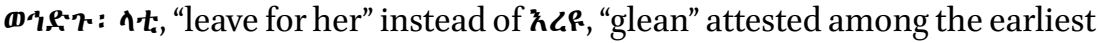
manuscripts. The younger witnesses have conformed the text to Hebrew MT,

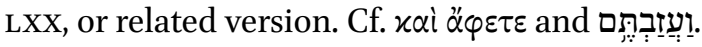

\subsubsection{Amos ${ }^{43}$}

Two sets of four variation units each will suffice to illustrate the transmission history of Amos in Ethiopic. The first set divides the earlier and later manuscripts. ${ }^{4}$

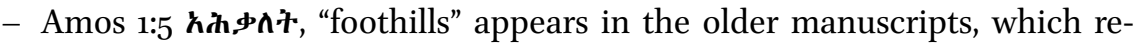
sulted from reading $\pi \varepsilon \delta \delta^{\prime} \circ v \Omega v$, "plain of On" as $\pi \varepsilon \delta \delta^{\prime} \omega \nu$. Later manuscripts

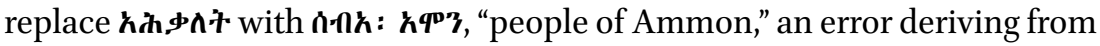

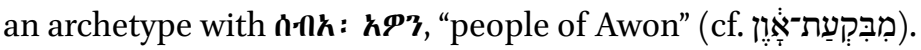

- Amos 1:5 Whereas the older witnesses attest the nearly nonsensical "bl, "good" (LXXX Xppav = "ic), the newer codices replace the word with a transliteration of the Hebrew קָירָ (\$ $\mathbf{L}=$ Qerä).

43 Curt Niccum provides this survey of the evidence for Amos based on his work as the Principal Investigator. The following manuscripts were transcribed: BN Abb. 35; BN Abb. 55; Bod Huntington 625 (Aeth d. 12); Cambridge Add. 1570; Davies Axum Church of Zion; EMIP 0654, 0746, o881, o949, 1029, 1063, 1070, 1095, 2007; EMML 0036, о349, 1481, 1768, 1842, 2080, 2440, 6686, 6930, 7584; Gunda Gunde 106, 152, 181, 203; IES Oo77, o436; Jerusalem Patriarchate 5; Princeton Garrett Ethiopic 7; UNESCO 10.04; UNESCO 10.34; UNESCO 10.65; Vat Cerulli 75; Wien 16. The test passages were: 1:1, 5-6, 11; 2:9; 3:3-4, 9; 4:2-3; 5:5-7, 16; 6:14; 7:14; 8:8, 14-9:1; 9:6-9, 14-15.

44 In all of these examples, the Latinized Text goes its own way. For example, at 1:5 it reads $\boldsymbol{\phi} \mathbf{\phi} \boldsymbol{\Lambda}: \boldsymbol{q} \boldsymbol{\rho} \boldsymbol{T}$, "valley of idols" = campo idoli. 
- Amos 2:9 Although most later textual alterations were imported from other traditions, internal stylistic improvements occasionally appear. In this verse, the more recent manuscripts add $\mathbf{8}: \mathbf{q}$, "strong," making the phrase "strong like a strong oak" formally parallel to the preceding "tall like a tall cedar." Cf.

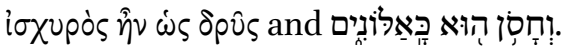

- Amos 5:7 The older and newer manuscripts diverge significantly in this

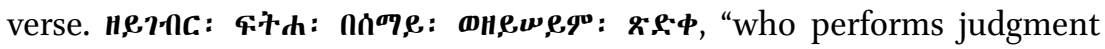
in heaven and who establishes righteousness" appears in the former and

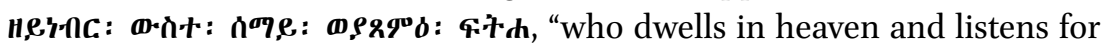
judgment" in the latter. The reason for this development is unclear, but scribal error is likely the culprit. That the newer reading became ubiquitous

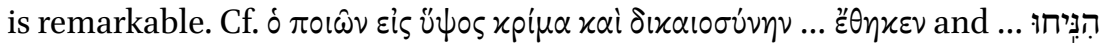

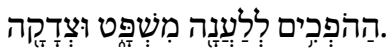

The second set of variation units identifies individual clusters within the broader history of transmission. (Consult Fig. 2.)

- Amos 1:1 The opening line of the book announces an oracle "about Jerusalem" (LXX i $\pi \dot{\rho} \rho$ I $\varepsilon \rho \circ v \sigma \alpha \lambda \eta \mu)$ in the earliest text. ${ }^{45}$ By the seventeenth century,

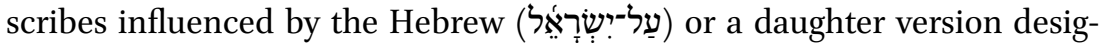
nated the oracle instead as "about Israel."46 Around the same time, these two readings were conflated to either "concerning Jerusalem and concerning Israel" or "concerning Israel and concerning Jerusalem."47 Within that same century, other conflate readings began to appear. ${ }^{48}$ The Latinized version reads "against Israel" (= super Israhel) ${ }^{49}$

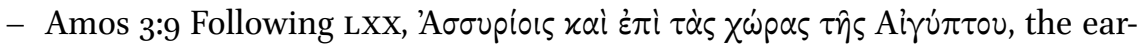
liest attested text commands that Israel make an announcement to the regions of "Assyria (4.c.n, "Fars," i.e., Persia) and Egypt." The Hebraicized cluster and the Latinized Text change the intended audience to "Azoton and Egypt." 50 The Standardized Text and modern Textus Receptus identify the recipients as "Ammon and Assyria." ${ }^{11}$ Naturally, the readings are eventually

\footnotetext{
45 Axum Zion; BN Abb. 55; EMIP 654, 1029; EMML 1768, 2080*, 7584; G G 152, 181, and 203.

46 BN Abb. 35; Emip 881; EmmL 36, 349, 1481, 6686; Princeton 7; and unesco 10.65.

47 The former is read by Cerulli 75 , EMIP 2007, EMML $2080^{c}, 6930, \mathrm{GG}_{106}$, Jerusalem $5 \mathrm{E}$, and UNESCO 10.04 and the latter by EMIP 1063 .

48 EMIP 1070, 1095, and IES 77 read "concerning Samaria and concerning Jerusalem" and EMIP 746, EMML 1842, and 2440 have "concerning Jerusalem and concerning Samaria."

49 EMIP 949 and UNESCO 10.34.

50 BN Abb. 35, EMIP 881, EMML 1481, and UNESCO 10.65 constitute the Hebraicized cluster.

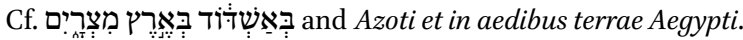

51 EMIP 2007, EMML 2440, G G 106, and UNESCO 10.04 transmit the Standardized Text and
} 
conflated. EMIP 746 has "Ammon, Assyria, and Egypt" and a small cluster (EMML 349, 6686; Princeton 7) expands even further to "Ammon, Azoton, Assyria, and Egypt."

- Amos 7:14 In the famous passage where Amos disavows his role as prophet, he protests in the earliest attested text that he is merely a $\boldsymbol{\omega} \boldsymbol{\varphi} \mathbf{m}: \mathbf{n} \mathbf{n} \boldsymbol{n}$, "vendor of figs" ( $x \nu i \zeta \omega \nu \nu \sigma u x \alpha \dot{\mu} \mu \nu \alpha)$; the reference to his goat herding profession ( $\alpha i \pi \dot{\lambda} \lambda \circ \varsigma$ ) is omitted. In the Standardized Text and modern Textus Receptus,

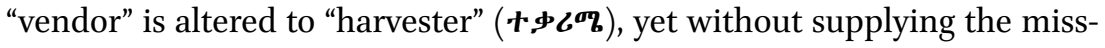
ing reference to Amos's animal husbandry. The Hebraicized cluster restores

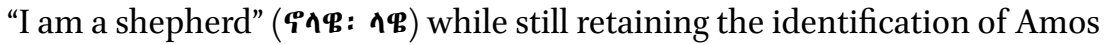

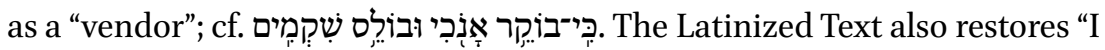

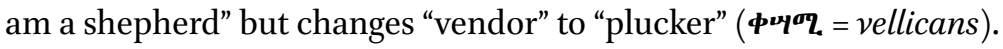

- Amos 9:7 The prophet lists foreign nations who, like Israel, have benefitted from God's salvific intervention. The earliest attested text refers to God's deliverance of "Israel from Egypt, the Ilofəli from Cappadocia, and Syria from

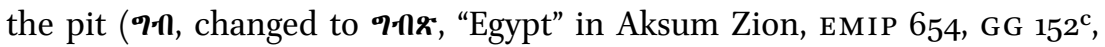

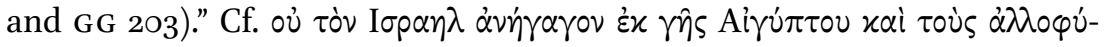

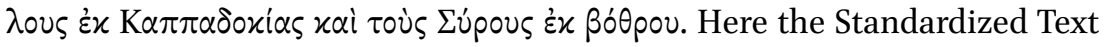
is divided with one branch stating that God delivered the Israelites "from Egypt and from the Ilofəli and Syria from Egypt"52 and the other declaring that God saved Israel "from Chaldea and from Məkaran and from Egypt," with "Chaldea" and "Məkaran" resulting from an incorrectly read Arabic text. ${ }^{53}$ The modern Textus Receptus also preserves two different readings: with Israel rescued "from Chaldea and from Məkaran and from Egypt and from Ilofəli" in one cluster ${ }^{54}$ and "from Chaldea and from Məkaran and from Syria and from Egypt" in another. ${ }^{55}$ EMML 6930, another member of this group, conflates both streams. The cluster more directly influenced by Hebrew retains the first two pairings found in the earliest attested text but alters the last to "Aram from Məkaran"; cf. Another cluster has Israel brought out of Egypt, Ilofəli, and Cappadocia, and "Abraham out of Syria," ${ }^{26}$ yet members of a related cluster fail to include Cappadocia in that

Cerulli 75, EMIP 1070, 1095, EMML 1842, 6930, and IES 77 represent the modern Textus Receptus.

52 Camb Add. 1570; EMIP 2007; and G G 106.

53 EMIP 746; EMML 2440; and UNESCO 10.04.

54 EMIP 1070; EMML 1842; and IES 77.

55 Cerulli 75 and EMIP 1095 .

56 EMML 249, 6686; and Princeton 7. 
list. ${ }^{57}$ Finally, the Latinized version has a word-for-word rendering of the Vulgate with Israel coming out of Egypt, Palestine out of Cappadocia, and Syria out of Cyrene.

\subsubsection{Obadiah $^{58}$}

The manuscripts in our sample for Obadiah clearly divide into older and younger branches. ${ }^{59}$ The following variants characterize this distinction: ${ }^{60}$

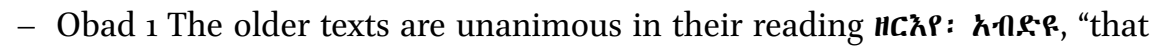
which Obadiah saw." Six out of eight (75 percent) of the younger manuscripts

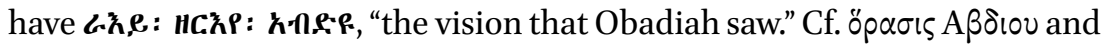
חד:

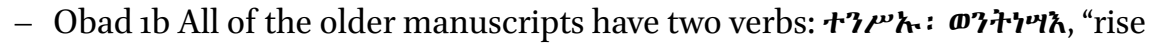
up and let us rise up." The younger manuscripts are unanimous in omit-

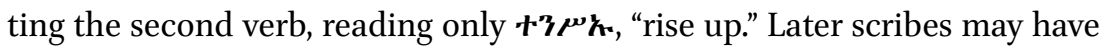

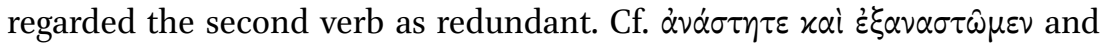

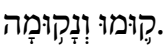

- Obad 9 The older manuscripts unanimously read ritory of," while six out of eight (75 percent) of the younger manuscripts

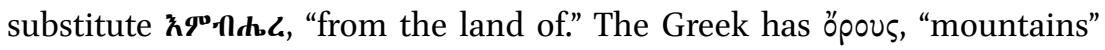
but translators often mistook this word as a form of öprov. (See Deut 32:8 above for a similar error.) The shift from $\boldsymbol{\rho \omega}_{\boldsymbol{A}}$ to $\mathbf{n d \mathbf { h }}$. is probably related to diachronic changes in the native language. According to Leslau, there remains no Amharic cognate of $\boldsymbol{P}_{\boldsymbol{N}} \boldsymbol{A}$ meaning "territory" in common use. ${ }^{61}$ Cf. מֵהֶ,.

- Obad 17 The younger texts unanimously begin the verse with an additional

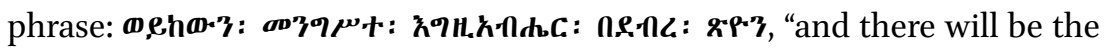
kingdom of God on Mount Zion," which agrees neither with the Greek nor

$57 \quad$ EMIP 1063 and EMML 36.

$5^{8}$ Garry Jost provides this survey of the evidence for Obadiah based on his work as the Principal Investigator. The entirety of Obadiah was transcribed in the following manuscripts: BN Abb. 35; BN Abb. 55; Bod Huntington 625 (Aeth d. 12); Bod Bruce 74; Cambridge Add. 1570; Davies Axum Church of Zion; EMIP 0746, o881, o949, 1029, 1063, 1070, 1095, 2007; EM ML оо36, o349, 1481, 1768, 1842, 2080, 2440, 6686, 6930, 7584; Frankfurt Ms.Or.1o; Gunda Gunde 106, 152, 181, 203; IES 077, 436; Jerusalem Patriarchate JE5E; Princeton Garrett Ethiopic 7; UNESCO 10.04; UNESCO 10.34; UNEsCO 10.65; Vat Cerulli 75; and Wien 16.

59 Setting aside the two manuscripts with a Latin Vorlage.

6o More precisely, these variants reflect a distinction between the primary cluster of the older and the primary cluster of the younger manuscript traditions.

61 Wolf Leslau, Concise Amharic Dictionary (Wiesbaden: Harrassowitz, 1976), 85. 
the Hebrew. Perhaps the scribe was influenced by the very final words of

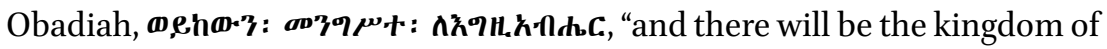
God," or by an external source.

The following two variants show a mistake in the earliest manuscripts followed by an attempt to correct it, which eventually did not win the day. Instead, the mistake persists through the Standardized Text form and into the modern Textus Receptus:

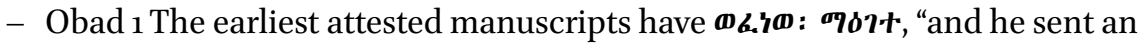

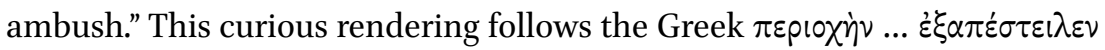

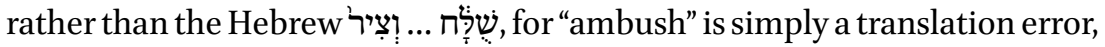

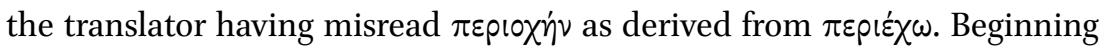
in the seventeenth century, several manuscripts provide a correction, read-

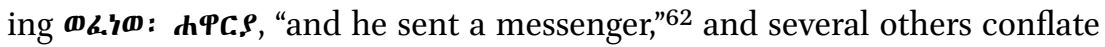

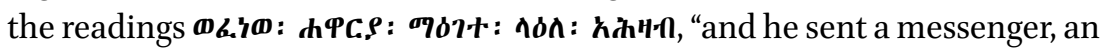
ambush upon the nations." ${ }^{63}$ Since the corrected reading "and he sent a messenger" is consistent with Greek and Hebrew, one would expect it to carry the day. However, the majority of manuscripts preserve the earlier reading. The two manuscripts that have a Latin Vulgate Vorlage correct the reading to "and he sent a messenger to the nations." 64

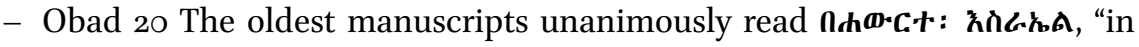
the lands/regions of Israel." Since both Greek and Hebrew have "Jerusalem"

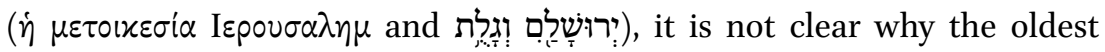
manuscripts have "Israel." It is worth noting that all manuscripts refer to Israel several words earlier in the verse, which may explain the corresponding "Israel" (instead of "Jerusalem") here. Several manuscripts provide a cor-

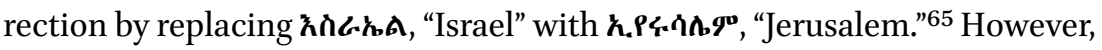
as was the case in the previous variant, these corrected texts did not attract a sufficient following, and so it was the earlier reading "Israel" that persisted through the Standardized Text to the modern Textus Receptus.

The following variants help characterize the modern Textus Receptus: ${ }^{66}$

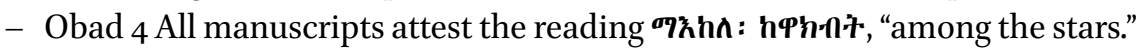
Among the collated witnesses, only one seventeenth century manuscript, ${ }^{67}$

\footnotetext{
62 BN Abb. 35; EMIP 881; and UNESCO 10.65.

63 EмML 349, 1481, 6686; and Princeton Garrett Ethiopic 7.

64 EMIP 949 and UNESCO 10.34.

65 These manuscripts include Cambridge Add. 1570 (a sixteenth century manuscript), some that were mentioned in the previous variant (BN Abb. 35, EMIP 881, UNESCO 10.6), and the two Latin-based manuscripts.

66 The modern Textus Receptus manuscripts are EMIP 1070, 1095, IES77, and Vat Cerulli 75.

67 EMIP 2440.
} 
an eighteenth century manuscript, ${ }^{68}$ and the four Textus Receptus manu-

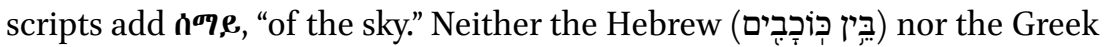
( $\dot{\alpha} \nu \dot{\alpha} \mu \varepsilon \dot{\varepsilon} \sigma \nu \tau \tau \hat{\omega} \nu \alpha \dot{\alpha} \sigma \tau \rho \omega \nu)$ have this plus.

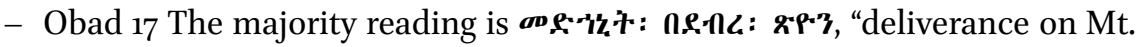
Zion," attested by thirty manuscripts. One seventeenth century manuscript ${ }^{69}$ and all four manuscripts of the modern Textus Receptus read instead

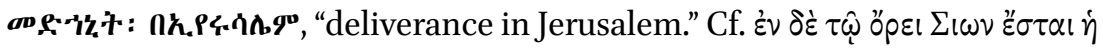

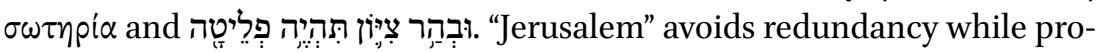
viding a satisfactory parallel to "Zion," which appears in the newly added phrase noted above.

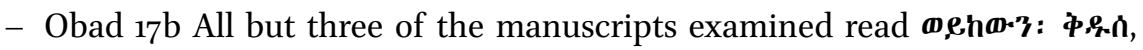

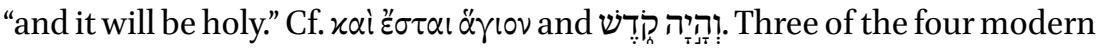

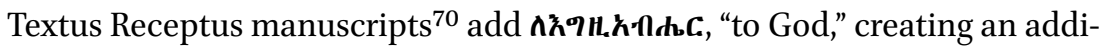
tional parallel to the recently added phrase. (See notes on Obad 17 above.)

\subsubsection{Jonah ${ }^{71}$}

Ethiopic Jonah is transmitted in the typical patterns described above as well as in a text type that is a translation of the Latin Vulgate. ${ }^{72}$ The discussion below focuses on the typical pattern as the translation of the Latin Vulgate clearly was produced by a different mechanism than was the rest of the extant manuscript tradition.

The earliest attested text ${ }^{73}$ and the earliest form of the "Transitional Text"74 differ in a number of places that can be divided into three categories: 1) readings found in the earliest attested text are closer to the Greek than those of the Transitional Text; 2) readings preserved in the Transitional Text are closer to the Greek than the earliest attested readings; and 3) readings not so easily placed in either category. Examples from each category follow:

- Jonah 2:4 The second-person singular verb form in the Transitional Text,

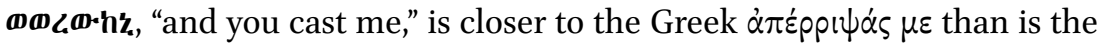

68 EMIP 746.

69 EMML 1842.

70 EMIP 1070; IES77; and Vat Cerulli 75.

71 Jeremy Brown provides this survey of the evidence for Jonah based on his PhD dissertation "Jonah in the Ethiopic Biblical Tradition" at The Catholic University of America. Brown has transcribed 103 manuscripts of Ethiopic Jonah in their entirety. For a complete list, see "Jonah in the Ethiopic Biblical Tradition."

72 This text type is transmitted in three manuscripts: EMIP 949; EMML 7942; and UNESCO 10.34 .

73 This group is called Earliest Attested 1 in Brown's dissertation.

74 In the dissertation, this appears as Cluster 2 of Earliest Attested 2. 
third-person singular form of the verb found in the earliest attested text,

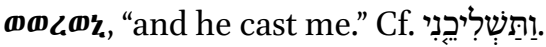

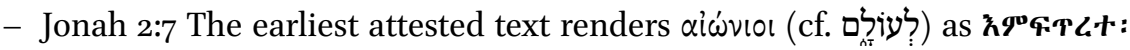
$\boldsymbol{\Phi} \boldsymbol{\cap} \boldsymbol{A P}$, "from the creation of the world." The Transitional Text lacks an equivalent.

- Jonah 2:8 The Transitional Text orders the two clauses of the strophe in the same order as the Greek, but the earliest attested text has the two clauses in the opposite order. However, the earliest attested text translates $\dot{\alpha} \pi^{\prime} \dot{\varepsilon} \mu 0 \hat{0}$ with ก^on,P, "upon me," whereas the Transitional Text does not offer a trans-

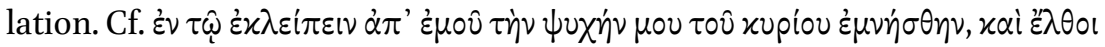

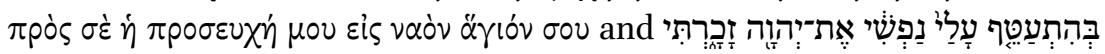

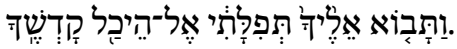

There is a strong divide between these two earlier text types and the two text types that come after them. The Standardized Text type is a revision of one branch of the earliest attested text (Earliest Attested 2 rather than Earliest Attested 1). The differences between the Standardized Text and its antecedents are often due to cross-pollination from other sources such as liturgical or biblical texts, other text types of Ethiopic Jonah, or with an external source such as an Arabic translation of the Syriac Peshitta.

- An example of cross-pollination with an external source is found in Jonah

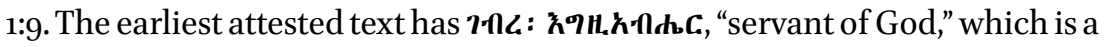

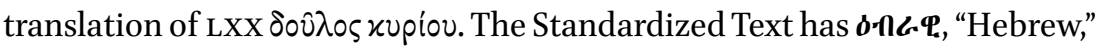
which is a translation of an Arabic source translated from a Syriac text based on Hebrew (עִבְריד).

- Jonah 2:4-10 The reading of the earliest attested text is largely replaced in the Standardized Text with the version of these verses found in the Seventh Biblical Canticle as transmitted in the Ethiopic Psalter.

- Jonah 4:2 The Standardized Text has a plus of or $\boldsymbol{e}: \mathbf{\phi}$, "and righteous," after

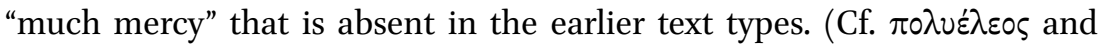

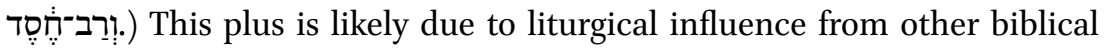
texts, such as Ps 85:15.

The modern Textus Receptus revises the Standardized Text. Its revisions often blend or conflate elements of one strand of the earliest attested tradition and the Standardized Text. For example, the Textus Receptus conflates the two

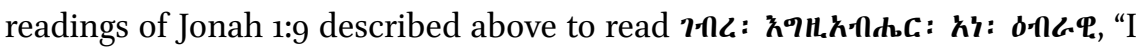
am a servant of God, a Hebrew." In addition, the modern Textus Receptus is characterized by longer readings than those found in the earlier text types. The twentieth-century witnesses attest expanded readings in sixteen of the verses of Jonah. 


\subsubsection{Haggai ${ }^{75}$}

In Ethiopic Haggai, the distinctions between the two earliest attested forms of the text cover fifteen points of variation. Several of these are easily identified as scribal errors (such as the confusion between $\mathbf{h}^{\boldsymbol{\sigma o}}$, "when," and hav, "that," in 2:16 or the repetition of '\$:त, "soul," in 2:13), but there are a few more telling variants worth noting here:

- Hag 1:2 The earliest attested text reads '.'h', "was not," whereas the Transitional Text has h.nq h, "had not arrived." Cf. oטх

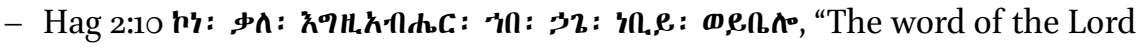
came to Haggai the prophet, and he said to him," found in the earlier wit-

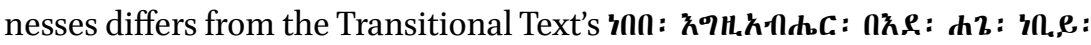

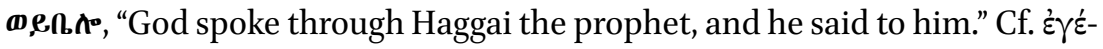

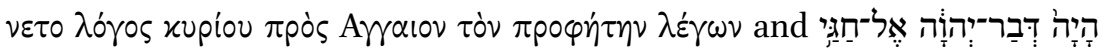

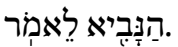

Perhaps the most distinguishing feature in the earliest attested text, however, is one with great stemmatic importance for the later transmission of Haggai: the appearance of an angel (makh) in the middle of one of Haggai's oracles. As the angel only appears in locations where Haggai's name is mentioned in LXX (2:13a and 2:2ob), its presence in the text is most easily explained as a result of

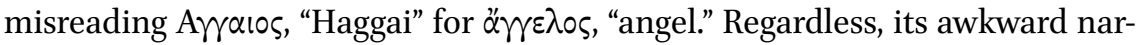
rative locale has resulted in two different paths of transmission beyond the earliest attested texts. First, the Transitional Text refers neither to the angel nor to Haggai. This minus remains in later texts that build on the Transitional Text. Second, the Standardized Text and modern Textus Receptus embrace the presence of the angel, and indeed further explain in v. 20 that it was the Lord

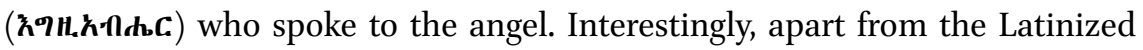
Version and a single interlinear correction in BN Abbadie 35, Haggai's name is not found among the manuscripts studied, even those manuscripts exhibiting influence from the MT.

The textual history of Ethiopic Haggai, from its earliest attested form through the Standardized Text and into the modern Textus Receptus, is succinctly displayed by the dating of Haggai's four oracles $(2: 1,10,18,20)$, which

75 Samuel Aldridge provides this survey of the evidence for Haggai based on his work as the Principal Investigator. Haggai was transcribed in its entirety from the following manuscripts: BN Abb 35; BN Abb 55; Bod Huntington 625 (Aeth d. 12); Cambridge Add. 1570; Davies Axum Church of Zion; EMIP 0746, o881, o949, 1029, 1063, 107 O (= EMML 5595), 1095, 2007; EMML о०36, o349, 1481, 1768, 1842, 2080, 2440, 6686, 693o, 7584; Frankfurt Or 10; Gunda Gunde 106, 152, 181; IES 077, 436; Jerusalem Patriarchate JE5E; Princeton Garrett Ethiopic 7; UNESCO 10.04; UNESCO 10.34; UNESCO 10.65; and Vat Cerulli 75. 
account for four of the sixteen points of variance that separate these three forms from one another. Interestingly the four oracles are all dated the same in the Ethiopic, and they read thus:

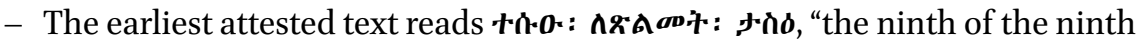
darkness (i.e., month)."

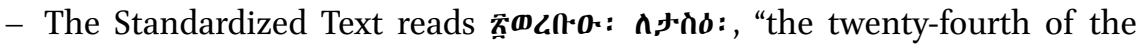
ninth."

- The modern Textus Receptus conflates these two readings to read tin:0:

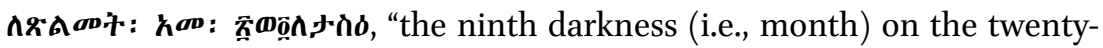
fourth of the ninth."

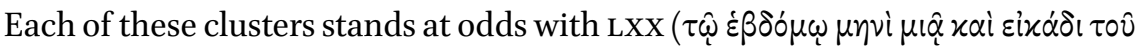

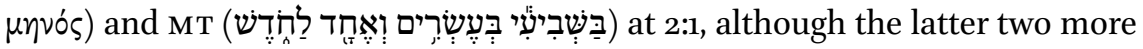
closely fit the Greek and Hebrew at 2:10, 18, and 20.

\subsection{Scribal Idiosyncrasy}

Despite the remarkable uniformity of the general tradition, we can identify and describe the degree to which individual scribes introduced idiosyncratic readings into their copies. By organizing the spreadsheet of the transcription data so that words of the same root appear in a single column, each column bears witness to one of three phenomena: 1) complete uniformity, where every manuscript has the same root word; 2) cluster variation, where one group of manuscripts has a reading that others do not; or 3) unique readings, where one manuscript varies from all the rest. For example, an excerpt of the transcriptions of Amos 9:6a below shows that there is:1) complete uniformity with HPA38: "the one building," which appears in one form or another in all collated witnesses; 2) cluster variation where $\boldsymbol{\delta c} \mathbf{c} \boldsymbol{中}$, "his ascension" appears only in the Latinized Text ( $\mathrm{W}_{17}$ and $\mathrm{W}_{18}$ ) against $\mathbf{8 \cdot C} \cdot \mathbf{c}$, "his upper chamber," which is found

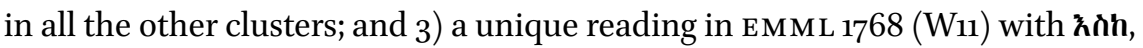
"as far as" replacing the otherwise ubiquitous $\boldsymbol{\omega} \cdot \boldsymbol{\lambda} \boldsymbol{+}$, "in."

\begin{tabular}{|c|c|c|c|c|c|c|c|c|}
\hline W17 & Amos & og:o6a & HP A3\% & $\boldsymbol{a} \cdot \boldsymbol{\lambda} \boldsymbol{t}$ & & nage & & oc:7p \\
\hline$W_{18}$ & Amos & o9:o6a & HPd"YR & $\boldsymbol{D} \cdot \boldsymbol{\lambda} \boldsymbol{T}$ & & $n^{a q}, e$ & & oC.7. \\
\hline W11 & Amos & o9:०6a & HPA38 & & hinh & $\left.n^{\sigma}\right), e$ & R.C.d & \\
\hline W25 & Amos & og:o6a & HPd"Y: & $\boldsymbol{D} \cdot \boldsymbol{\lambda} \boldsymbol{T}$ & & $n^{\sigma 9}, e$ & R:C.dh & \\
\hline
\end{tabular}

Assuming that unique readings such as the one found in Amos 9:6 by EMML 1768 attest scribal idiosyncrasy rather than readings of other as yet unidentified manuscript clusters, a typical scribe creates fewer than ten idiosyncratic readings within the sampled text, but a small number have more than twenty or thirty, up to two and three standard deviations off the norm. By aggregat- 
ing these statistics, we achieve a profile of the entire cohort of scribes whose manuscripts have been collated. This body of data provides an interesting insight into patterns of scribal behavior. With it, one can detect, for instance, if there may be epochs or locations in which scribal idiosyncrasy may have been allowed or prohibited. Judging by the mean, manuscripts produced at the monastery of Gunda Gunde, for instance, show a remarkable lack of idiosyncrasy. This sort of profile of the behavior of the cohort of scribes is possible only because of the statistical approach to the work and the fact that no piece of data is simply excluded from consideration because it is unique.

\subsection{Contact with the $\mathrm{MT}^{76}$}

Opportunities for Ethiopian contact with the Hebrew Bible existed before the country's conversion to Christianity in the fourth century CE. As a major conduit for international trade, Ethiopians regularly encountered a wide variety of people until the Aksumites retreated away from the coast into the highlands. Even as the nation became more isolated geographically and economically, religiously it remained tethered to other locales, including a notable, although perhaps not continual, presence in Jerusalem. And occasionally Jews traveled to Ethiopia, sometimes having an impact on the royal family and therefore their religion.

Nevertheless, it is only late in Ethiopia's literary history when influence from the Hebrew Bible appears. Its greatest impact is channeled through the "daughter versions." For many biblical books, an Arabic translation of the Syriac, which itself descends from a text close to the MT, influenced the creation of the Standardized Text. Yet, there are a few places where translations (e.g., Prov 10:4) and transliterations (e.g., Neh 11:17 and Dan 11:30) of Hebrew rather than Arabic betray direct Hebrew influence. This evidence fits what we find stated in colophons associated with the Standardized Text, namely that the reviser(s) employed Hebrew along with Arabic and Coptic sources. ${ }^{77}$ The later, nineteenth century revision against the Latin Vulgate also produced a text much closer to the Masoretic Text than its predecessors.

More concrete contact with the Masoretic Text does appear, although it is sporadic up until modern times. One of the earliest examples comes from BN éth. 7 , a fourteenth century manuscript of Job and Daniel. In the margins of that manuscript, a later reader (fifteenth century?) added notes where a certain Marqoryos observed that the codex's text deviated from the Hebrew.

\footnotetext{
76 See, further, E. Ullendorff, "Hebrew Elements in the Ethiopic Old Testament," JSAI 9 (1987): $42-5$ o.

77 See вм Add. 24.991, fol. $64^{\mathrm{v}}$.
} 
The most notable artifact in this regard is in the Cambridge University Library. Manuscript Add. 1570, apparently commissioned by Empress Maryam Sena, was completed around 1588 . The intention seems to have been to produce an Ethiopic Bible more closely aligned with the Hebrew. The scribe, Jacob the Israelite, generally made minor adjustments to his base text. Only in those places in which the Ethiopic dramatically varied from the Hebrew, such as Ezekiel 42-48, did he extensively revise or create a new translation. Despite royal sanction, this manuscript appears to have had no impact on the later transmission history of Ethiopia's Bible.

Another notable intersection with the Hebrew MT occurs with Kidane Wold Kifle (1870-1944), who lived in Jerusalem and had access to the Hebrew text as well as to rabbinic literature. Alaqa Kidane $^{78}$ wrote an influential Ge'ez and Amharic commentary on the book of Ezekiel that was based on a fresh translation from the Hebrew into Ge'ez. Previously unattested readings are present in almost every chapter. For instance, Ezek 2:2 in Kidane's edition reads "the

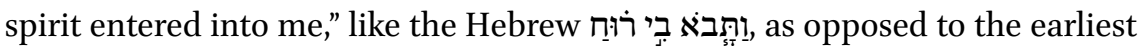
attested text's more idiomatic "the spirit came upon me." Perhaps, Ezekiel 42 is even more noteworthy. In the earliest manuscripts, because of the translator's limited grasp of Greek, the Greek technical terms are either transliterated or omitted. Alaqa Kidane, on the other hand, translated most of them from the Hebrew, although he left one Greek transliteration untouched. In comparison, Jacob the Israelite (Cambridge Add. 1570) translated all termini technici from the Hebrew.

\section{3}

\section{Conclusion}

Having already produced reports of our work related to Psalm 151 and Jeremiah for publication in other venues, ${ }^{79}$ we plan to publish five book-length reports within a year on Deuteronomy, Ruth, Amos, Obadiah, and Haggai. The data sets for several more books are completed and awaiting analysis and write-up: Psalms, Song of Songs, Habakkuk, Hosea, Ecclesiastes. We also have transcriptions of thirty or more manuscripts for Judges, Esther, Job, Daniel (including all of Susanna and Bel and the Dragon), Joel, Micah, Nahum, Zechariah, and Malachi.

78 Alaqa signifies a master church scholar. One refers to Ethiopian men by their first name (the second name is that of their father).

79 See Jost and Delamarter, "Digital Methodology," forthcoming; and Delamarter, "Cave 11," $390-407$. 
The enduring value of the project, though, will be in the digital archive of data we generate and the tools developed for analysis and visualization. The data produced so far have advanced our understanding of the transmission history of the Bible in Ethiopia. First, the more precise picture allows us to map the historical developments of the text with a level of granularity virtually unexplored in earlier studies. In addition to the general distinction between older and younger texts made in those studies, smaller clusters have also been identified, including a fascinating chapter in Ethiopia's transmission history: a thorough revision based on the Latin Sixtine Vulgate. The greater precision further highlights common catalysts for textual change in Ethiopia such as intertextuality, influence from external textual traditions (primarily Arabic and Hebrew), and scribal error. It also brings to the fore the limited number of stylistic improvements in a tradition originating with a generally word-for-word rendering of the Greek Vorlage with syntactical features unnatural in Ge'ez. ${ }^{80}$

Second, the more complete picture the project provides is just as important. For various reasons, it has been standard practice in modern, Western scholarship to produce editions of Ethiopic books of the Bible in which the evidence of the manuscripts after the seventeenth century has been systematically excluded. But the goal of textual criticism is understanding the history of textual transmission, not just reconstructing an early exemplar. Further, Ethiopian Orthodox Christianity-like other ancient and non-Western expressions of Christianity - finds the truest and best form of its authoritative texts not in the ipsissima verba of a theoretical text form that lies at the origins of the tradition, but in the unfolding text continuously being refined by the community generation after generation. Thus, arbitrarily omitting centuries of data falls far short of the text-critical goal.

It was typical of colonialism that it exploited the cultural and physical resources of dominated cultures for its own purposes and ignored or-worsesuppressed the use of those resources by the cultures for their own purposes. ${ }^{81}$

8o On this characteristic of the earliest attested text, see Michael Knibb, Translating the Bible: The Ethiopic Version of the Old Testament (Oxford: For the British Academy by Oxford University Press, 1999), 83-86.

81 As the British and Foreign Bible Society, and its successor societies, supported the production of Bibles not only in English but also Bible translation projects into the languages of new cultures, there were always tensions between what they thought was the appropriate form of the Bibles to be produced and what the target populations wanted. The following titles are but a few that explore such dynamics: George Kam Wah Mak, "To Add or Not to Add? The British and Foreign Bible Society's Defence of the 'Without Note or Comment' Principle in Late Qing China," Journal of the Royal Asiatic Society of Great Britain \& Ireland 25, no. 2 (2015): 329-354; T.J. Makutoane and J.A. Naudé, "Colonial Interference in 
The documentation of textual history-up to and including its most recent expressions-has the added benefit that it respects and values in a tangible way the full tradition and offers materials that can address the needs of text critics and members of the indigenous community alike.

the Translations of the Bible into Southern Sotho," AcT 29, suppl. 12 (2009): 79-94; and R.S. Sugirtharaja, The Bible and the Third World (Cambridge: Cambridge University Press, 2001). 